\title{
Relationships Between Milk Culture Results and Treatment for Clinical Mastitis or Culling in Norwegian Dairy Cattle
}

\author{
O. Reksen, ${ }^{* 1}$ L. Sølverød,† A. J. Branscum,‡ and 0. Østerås* $†$ \\ *Department of Production Animal Clinical Sciences, Norwegian School of Veterinary Science, Oslo, Norway \\ †Department of Norwegian Cattle Health Services, TINE Norwegian Dairies Association, Ås, Norway \\ ‡Departments of Biostatistics and Statistics, University of Kentucky, Lexington, 40536
}

\section{ABSTRACT}

In quarter milk samples from 2,492 randomly sampled cows that were selected without regard to their current or previous udder health status, the relationships between the following outcome variables were studied: treatment of clinical mastitis; the joint event of either treatment or culling for mastitis; culling for all reasons; culling specifically for mastitis; and the covariates of positive milk culture for Staphylococcus aureus, Streptococcus spp., and coagulase-negative Staphylococcus spp., or other pathogens, or of negative culture for mastitis pathogens. Microbiological diagnoses were assigned at the cow level, and altogether 3,075 diagnoses were related to the outcome variables. The relation between the absence of pathogens and rich $(>1,500 \mathrm{cfu} / \mathrm{mL}$ of milk) or sparse $(\leq 1,500 \mathrm{cfu} / \mathrm{mL}$ of milk) growth of Staph. aureus were also assessed separately for each outcome variable. The hazard of treatment of clinical mastitis was greater for cows diagnosed with Staph. aureus compared with cows with no pathogens in all analyses. Cows with sparse growth of Staph. aureus upon microbiological analysis were more likely to be treated for clinical mastitis, and cows with rich growth of the bacteria experienced a higher overall risk of culling when the models adjusted for cow composite milk somatic cell count. No difference between rich and sparse growth of Staph. aureus was found when mastitis was defined as the joint event of either culling for mastitis or treatment of clinical mastitis, and when the relationship with culling specifically for mastitis was assessed. The combined outcome of treatment and culling for mastitis was related to a positive diagnosis of Strep. spp. after cow composite milk somatic cell count was omitted from the model. Presence of Streptococcus spp. was also related to culling specifically for mastitis, whereas culling for all reasons and treatment of clinical mastitis was not related to a positive culture of Strep. spp. Presence of coagulase-negative Staph. spp. or other

Received November 10, 2005.

Accepted February 28, 2006.

${ }^{1}$ Corresponding author: Olav.Reksen@veths.no pathogens was not associated with either of the outcome variables.

Key words: cow, culling, mastitis, Staphylococcus aureus

\section{INTRODUCTION}

Bacteriological culture is routinely used to diagnose mastitis, and culture results are often the basis for treatment or culling decisions. Besides treatment costs and losses due to withholding of milk, culling may be the most expensive outcome of a positive milk culture of mastitis pathogens. Parity, stage of lactation, presence of infectious agents, reproductive status, and milk yield are factors known to influence culling decisions (Beaudeau et al., 1995; Gröhn et al., 1998; Neerhof et al., 2000). Moreover, culling risk has been associated with cow composite milk SCC (CMSCC) for cows culled for all reasons and because of mastitis (Caraviello et al., 2005; De Vliegher et al., 2005), and clinical mastitis has been related to increased risk of culling in several studies (Beaudeau et al., 1995; Gröhn et al., 1998; Neerhof et al., 2000). However, relatively little is known about the relationship between culling practices and positive culture of mastitis pathogens when sampling for bacteriological analyses is conducted irrespective of cow-level characteristics. Mastitis pathogens isolated in milk cultures in such samples of cows most likely originate from subclinical IMI or colonization of the udder.

The objectives of the present study were 3 -fold. First, we assessed the time to treatment of clinical mastitis following the isolation of mastitis pathogens predominantly from subclinical IMI or colonization of the udder. Second, we evaluated the association between time to culling, and specifically time to culling due to mastitis, and isolation of mastitis pathogens. Third, we assessed the influence of isolation of rich or sparse numbers of colony-forming units of Staphylococcus aureus on time to treatment of clinical mastitis, the joint event of either treatment or culling for mastitis, general culling, and culling due to mastitis. To address these issues, a representative sample of cows enrolled in the Norwegian 
Dairy Herd Recording System (NDHRS) were selected without regard to their present or previous udder health status.

\section{MATERIALS AND METHODS}

A survey of quarter milk cultures obtained in 3,538 samplings from 350 Norwegian dairy herds was conducted between January 19, 2000, and January 23, 2001. The microbiological diagnoses were assigned at cow level. The study population, design of the survey, and laboratory procedures have been discussed in detail previously (Østerås et al., 2006). Among all Norwegian dairy farms, $89.2 \%$ were enrolled in the NDHRS at the beginning of the investigation (Østerås, 2002). The present study involved cows that were enrolled in this system. Both herds and cows were subject to systematic random selection procedures such that every 50th Norwegian dairy herd was selected. Cows from the sampled herds were sorted according to their unique identity number and every fifth cow was selected after drawing the starting number randomly from 1 to 4 . The random selection of cows was conducted 4 times (quarterly) during the investigation period to ensure a representative collection from all 4 seasons. Each cow had the same chance of being selected each season.

Quarter milk samples were collected aseptically by trained advisors from the dairy industry. The individual milk samples were analyzed for the growth of microorganisms in accordance with the official procedure in Norway (Aursjø et al., 1993), based on the procedures of the International Dairy Federation $(1981,1987)$, with the exemption that isolates of Staph. aureus were categorized according to number of colony-forming units at cow level. The amount of Staph. aureus was regarded as rich when $>15 \mathrm{cfu}(\mathrm{n}=324)$ were found in at least one sample of $0.01 \mathrm{~mL}$ of quarter milk $(1,500 \mathrm{cfu} / \mathrm{mL})$, and was regarded as sparse when $\leq 15 \mathrm{cfu}$ were found upon microbiological analysis $(\mathrm{n}=374)$ in one or more quarters. Mastitis pathogens were regarded to be present when the following microorganisms were isolated from the milk samples: Staph. aureus; Streptococcus dysgalactiae; Strep. uberis; coliform bacteria (including Escherichia coli); CNS; Strep. spp.; Enterococcus spp.; Arcanobacter pyogenes; Bacillus spp.; and yeast. Staphylococcus aureus was regarded to be present when a coagulase-positive Staphylococcus spp. was diagnosed. When microbiological diagnosis differed between or within quarters in the same cow, the diagnosis first listed above was assigned. In the joint event of a positive diagnosis both for Staph. aureus and Strep. dysgalactiae, the diagnosis Staph. aureus was assigned at cow level. Microbiological diagnoses were categorized as Staph. aureus $(\mathrm{n}=698)$, Strep. spp. $(\mathrm{n}=124)$, and
Table 1. Primary reason for culling as reported by the farmers $(n=$ 3,075)

\begin{tabular}{lrr}
\hline Culling practices & $\mathrm{n}$ & $\%$ \\
\hline Impaired reproductive performance & 148 & 4.8 \\
Mastitis or high milk SCC & 181 & 5.9 \\
Teat lesions & 43 & 1.4 \\
Other diseases & 58 & 1.9 \\
Low milk yield & 43 & 1.4 \\
Aggressiveness-bad temper & 63 & 2.0 \\
Part of management strategy & 417 & 13.6 \\
(not specific for cow characteristics) & & \\
Milk quota regulations & 35 & 1.2 \\
Other & 109 & 3.5 \\
Not culled within 500 d postcalving & 1,978 & 64.3 \\
\hline
\end{tabular}

CNS or other udder pathogens $(n=267)$. A detailed discussion of culture analyses at the quarter level can be obtained from Østerås et al. (2006).

Herds taking part in the NDHRS maintain individual health sheets for each female animal in the herd, together with records on calving date, parity, and milk yield per day in a particular month in milk, CMSCC per day recorded bimonthly (every $2 \mathrm{mo}$ ), disease history, and reasons for culling. Norwegian farmers do not have access to veterinary drugs, so that the large majority of treatments are carried out by veterinarians and recorded in the NDHRS. Veterinary diagnoses of clinical mastitis were used in this study. Primary and secondary reasons for culling were recorded by the farmer in accordance with definitions supplied by the NDHRS (Table 1). Bimonthly CMSCC was measured from milk samples collected from 2 successive milkings using Fossomatic 5000 (Foss Electric, Hillerød, Denmark).

The values of milk yield and CMSCC that were used in the statistical analyses were those that were collected nearest and preferably before the date of sampling for microbiological examination. However, cows with no data on milk yield or CMSCC within 2 mo before or after microbiological analysis were omitted from the study. Quarter milk samples from 2,492 cows were included in the study. Microbiological diagnoses were assigned at cow level and altogether 3,075 diagnoses were related to the outcome variables. A total of 1,207 cows were sampled once, 538 cows were sampled twice, 62 cows were sampled 3 times, and 2 cows were sampled 4 times.

The relationships with the outcome variables were also investigated in a subset of the data including only cows with a negative milk culture or a positive diagnosis for Staph. aureus. Because cows with other pathogens than Staph. aureus upon milk culture were omitted from these analyses, 2,684 microbiological analyses from 2,216 cows were used when no pathogens upon microbiological analysis compared to rich or sparse 
growth of Staph. aureus were used as covariates in the models. To avoid interference with management decisions, the findings from the microbiological analyses were not reported to farmers. The median herd size in the study was 15.1 cows (range $=3$ to 99). Purebreed Norwegian Red cattle comprised $97.7 \%$ of the study population.

\section{Statistical Analyses}

Separate statistical analyses involving proportional hazards regression models that incorporated random cow effects to account for repeated observations within cows were fitted using SAS version 8.12 (Allison, 1995) and S-Plus 6.0 (2001, S-Plus for Windows, Vol. 2, Insightful Corporation, Seattle, WA). $P$-values $\leq 0.05$ were regarded as statistically significant. The models were used to characterize the relationships between the microbiological diagnoses and 1) time to treatment of clinical mastitis and the joint event of either treatment or culling for mastitis, 2) time to culling either due to mastitis, or 3) general culling. The microbiological diagnoses were categorized either as (a) samples without pathogenic microorganisms upon microbiological analysis vs. samples with a positive culture for Staph. aureus, Streptococcus spp., or the joint category of CNS plus other pathogenic organisms, or (b) samples without pathogenic microorganisms vs. samples with a positive culture for either rich or sparse growth of Staph. aureus.

The analyses adjusted for previous history of clinical mastitis, parity, milk yield, and the natural logarithm of CMSCC (lnCMSCC). Specifically, previous history of clinical mastitis was dichotomized so that it reflected whether a cow had been treated for clinical mastitis before she was sampled for microbiological analysis during the current or preceding lactation. Parity had 3 levels: namely first-parity cows, second-parity cows, and $\geq 3$ parities. The continuous covariates were milk yield and lnCMSCC. All models were also run without lnCMSCC included, and hazard ratio (HR) for the milk culture results was reported together with the corresponding $P$-values obtained in these analyses. Calving season and season of microbiological sampling were grouped quarterly in winter, spring, summer, and fall. However, these covariates were excluded from the models due to lack of statistical significance. The backwards selection procedure was used.

The time to event was defined as time from sampling to treatment of clinical mastitis (case 1). Observations were censored if the event of interest had not occurred within $500 \mathrm{~d}$ after calving or if the animal had been culled within this time period (Table 2). To account for informative censoring due to cows culled because of mastitis, a separate analysis was conducted where the event of interest was defined as a composite of treatment of clinical mastitis and culling for mastitis. The latter was assigned when mastitis was recorded by the farmer as the primary reason for culling.

In additional analyses, time to event was defined as time from sampling to culling due to mastitis (case 2) or general culling (case 3). Culling for mastitis was regarded when mastitis was recorded, by the farmer, as the primary reason for culling. Cows not culled for mastitis within $500 \mathrm{~d}$ were censored in the case 2 analysis, and cows not culled within $500 \mathrm{~d}$ were censored in the case 3 analysis.

In fitting the models, each observation entered the risk set at the time of sampling for microbiological diagnosis. The covariates that were used in the calculation of the partial likelihood were recorded at the day of entry into the risk set. To account for repeated measurements on a single cow, a random cow effect was incorporated into all analyses, resulting in shared frailty models. Due to the random sampling procedure, clustering at herd level was not accounted for in the present analyses. This approach was supported by the fact that entering herd as a random effect to the model yielded close to identical parameter estimates as the current models.

Third-parity cows with no history of clinical mastitis and no mastitis pathogens upon microbiological diagnosis were the designated comparison (i.e., baseline) group in all analyses. Hazard ratios of the form $\mathrm{h}(\mathrm{t} \mid \mathrm{x}) /$ $\mathrm{h}\left(\mathrm{t} \mid \mathrm{x}^{*}\right)$ were used to compare cows with covariate vector $\times$ to cows with covariate vector $x^{*}$. A HR $>1$ implies an increased risk for cows with covariate combination $\times$ relative to those with covariate combination $\mathrm{x}^{*}$, and an $\mathrm{HR}<1$ implies a decreased risk. All models that were considered here had the following general form:

$$
\mathrm{h}_{\mathrm{ij}}(\mathrm{t})=\mathrm{h}_{0}(\mathrm{t}) \exp \left\{\mathrm{x}_{\mathrm{ij}} \beta+\varepsilon_{\mathrm{j}}\right\},
$$

where $\mathrm{h}_{\mathrm{ij}}(\mathrm{t})$ denotes the hazard at time $t$ for cow $j$ at event $i, \mathrm{x}_{\mathrm{ij}}$ denotes the vector of covariate information for cow $j$ at event $i$ with corresponding regression coefficient given by $\beta$. The random cow-effects, $\varepsilon_{\mathrm{j}}$, were assumed to be normally distributed with mean 0 and unknown variance.

The fitted models were assessed using deviance residuals (Allison, 1995). Plots of the log of the negative $\log$ of the estimated survivor function against log time showed no evident violations of the proportional hazards assumption in each of the 3 cases.

\section{RESULTS}

In this section we present results from the analyses corresponding to cases 1,2 , and 3 . First, we summarize 
Table 2. Distribution of number of samples in scenarios a) and b) that experienced the event of interest (1 through 4) or were randomly censored during the 500-d observation period, ${ }^{1}$ or were censored after the study ended (Type I)

\begin{tabular}{|c|c|c|c|c|c|c|}
\hline \multirow[b]{3}{*}{ Event } & \multicolumn{3}{|c|}{$\begin{array}{l}\text { a) No pathogens, Staph. aureus, Strep. spp., } \\
\text { and CNS or other pathogenic bacteria } \\
(\mathrm{n}=3,075)\end{array}$} & \multicolumn{3}{|c|}{$\begin{array}{l}\text { b) No pathogens, rich and sparse growth } \\
\text { of Staph. aureus }(\mathrm{n}=2,864)\end{array}$} \\
\hline & \multirow{2}{*}{$\begin{array}{l}\text { Event } \\
\text { (n) }\end{array}$} & \multicolumn{2}{|c|}{ Right censoring $(\mathrm{n})$} & \multirow{2}{*}{$\begin{array}{l}\text { Event } \\
(\mathrm{n})\end{array}$} & \multicolumn{2}{|c|}{ Right censoring $(\mathrm{n})$} \\
\hline & & Random $^{1}$ & Type I & & Random $^{1}$ & Type I \\
\hline 1) Treatment of mastitis & 605 & 907 & 1,563 & 523 & 790 & 1,371 \\
\hline 2) Treatment and culling for mastitis & 714 & 798 & 1,563 & 612 & 701 & 1,371 \\
\hline
\end{tabular}

${ }^{1}$ Culling within $500 \mathrm{~d}$.

the data on microbiological diagnoses, which is the primary predictor variable.

\section{Microbiological Diagnoses}

The distribution of microbiological diagnoses among the sampled cows is reported in Table 3 . The mean DIM for microbiological sampling was $164(\mathrm{SD}=94)$. Table 2 presents the number of events and the number of censored observations for each outcome.

\section{Case 1: Relationships Between Microbiological Diagnoses and Treatment of Clinical Mastitis, and the Joint Event of Either Treatment or Culling for Mastitis}

The associations between treatment of clinical mastitis and the covariates Staph. aureus, Strep. spp., CNS and other pathogens, no pathogens, parity, milk yield, lnCMSCC, and clinical mastitis history are evident from the fitted model presented in Table 4. In particular, the hazard of treatment of clinical mastitis among Staph. aureus-positive cows was $35 \%$ higher than the hazard for cows with a negative milk culture. Also, relative to cows with no history of clinical mastitis, cows that had been treated for clinical mastitis previously

Table 3. Distribution of microbiological diagnoses $(\mathrm{n}=3,075)$

\begin{tabular}{lrr}
\hline Microbiological diagnosis $^{1}$ & Count & $\%$ \\
\hline No pathogens & 1,986 & 64.6 \\
Staphylococcus aureus $^{2}$ & 698 & 22.7 \\
Streptococcus dysgalactiae, Strep. uberis, & 124 & 4.0 \\
and other Strep. spp. & 243 & 7.9 \\
Coagulase-negative Staph. spp. $^{\text {Other pathogens }}{ }^{3}$ & 24 & 0.8 \\
\hline
\end{tabular}

\footnotetext{
${ }^{1}$ When microbiological diagnosis differed between or within quarters in the same cow, the diagnosis first listed in the table was assigned.

${ }^{2}$ Coagulase-positive Staphylococcus spp.

${ }^{3}$ Enterococcus spp., Arcanobacter pyogenes, Bacillus spp., coliform bacteria including Escherichia coli, and yeast.
}

were twice as likely to be treated for subsequent clinical mastitis. Omitting lnCMSCC from the model did not provide significant estimates for the hazard of treatment in the milk culture categories; Streptococcus spp. (HR $=1.37, P=0.20)$, and CNS and other pathogens (HR $=1.23, P=0.22)$, whereas the HR for Staph. aureus was $1.51(P<0.01)$.

The fitted model presented in Table 4 was based on an analysis that used time to treatment of clinical mastitis as the response variable, but the estimates presented there are in line with estimates from the model that defined the response to include cows that were culled because of mastitis in addition to those that were treated for clinical mastitis. The calculated HR for the latter analysis were as follows: isolation of Staph. aureus vs. no pathogens, $\mathrm{HR}=1.43(P<0.01)$; isolation of Strep. spp. vs. no pathogens, HR $=1.38(P=0.14)$; isolation of CNS or other pathogens vs. no pathogens, HR $=1.11(P=0.51)$; first parity vs. third or later parities, HR $=0.81(P=0.09)$; second parity vs. third or later parities, $\mathrm{HR}=0.80(P=0.06)$; history of clinical mastitis, $\mathrm{HR}=2.05(P<0.01)$; milk yield, $\mathrm{HR}=1.03$ $(P<0.01)$; and $\operatorname{lnCMSCC}, \mathrm{HR}=1.29(P<0.01)$. For the milk culture categories, the estimated HR for Staph. aureus, Streptococcus spp., and CNS or other pathogens increased to $1.68(P<0.01), 1.74(P=0.01)$, and 1.28 $(P=0.12)$, respectively, when lnCMSCC was omitted from the model.

Table 5 presents the fitted model for case 1 when the covariates included rich or sparse growth of Staph. aureus, no pathogens, parity, milk yield, InCMSCC, and clinical mastitis history. Cows with rich growth of Staph. aureus had hazard for treatment of clinical mastitis that was $19 \%$ higher, whereas cows with sparse growth had hazard that was $45 \%$ higher than that for cows with no pathogens. An increased likelihood of treatment was also apparent for sparse growth of Staph. aureus after lnCMSCC was removed from the model. The estimated HR in this model were as follows: isolation of rich growth of Staph. aureus vs. no patho- 
Table 4. Relationships between treatment of clinical mastitis and covariates, predicted by a random-effects Cox proportional hazard model for time-dependent data ${ }^{1}$

\begin{tabular}{|c|c|c|c|c|}
\hline Covariate & $\beta$ & SE & $P$-value & $\begin{array}{l}\text { Hazard } \\
\text { rate }\end{array}$ \\
\hline No pathogens & - & - & - & - \\
\hline Staphylococcus aureus ${ }^{2}$ & 0.303 & 0.117 & 0.01 & 1.35 \\
\hline Streptococcus spp. & 0.152 & 0.245 & 0.54 & 1.16 \\
\hline CNS or other pathogens ${ }^{3}$ & 0.105 & 0.172 & 0.54 & 1.11 \\
\hline First parity & -0.181 & 0.132 & 0.17 & 0.84 \\
\hline Second parity & -0.206 & 0.127 & 0.10 & 0.81 \\
\hline Third or higher parities & - & - & - & - \\
\hline $\mathrm{LnCMSCC}^{4}$ & 0.183 & 0.042 & $<0.01$ & 1.20 \\
\hline Previous history of mastitis ${ }^{5}$ & 0.692 & 0.111 & $<0.01$ & 2.00 \\
\hline Milk yield & 0.029 & 0.008 & $<0.01$ & 1.03 \\
\hline
\end{tabular}

\footnotetext{
${ }^{1}$ Animals entered the risk set at the time of sampling for microbiological analysis and were observed until treatment of clinical mastitis, until culling, or for $500 \mathrm{~d}$ after calving $(\mathrm{n}=3,075)$.

${ }^{2}$ Coagulase-positive Staphylococcus spp.

${ }^{3}$ Coliform bacteria, including Escherichia coli; Enterococcus spp.; Arcanobacter pyogenes; Bacillus spp.; and yeast.

${ }^{4}$ Logarithmic-transformed cow composite SCC.

${ }^{5}$ Clinical mastitis history indicates whether a cow had been treated for clinical mastitis before it was sampled for microbiological analysis during the current or previous lactation.
}

gens, $\mathrm{HR}=1.38(P=0.04)$; and isolation of sparse growth of Staph. aureus vs. no pathogens, $\mathrm{HR}=1.59$ $(P<0.01)$.

The estimated HR in Table 5 are in line with the estimated HR based on the model where the event of interest was defined as the joined category for either treatment of clinical mastitis and culling for mastitis. However, the HR for isolates with more than 1,500 cfu of Staph. aureus/ml vs. isolates with no pathogens increased to $1.34(P=0.04)$ in the latter analysis and the estimated HR for the remaining covariates were as follows: isolates with sparse growth of Staph. aureus vs. no pathogens, $\mathrm{HR}=1.47(P<0.01)$; first parity vs. third or later parities, HR $=0.98(P=0.87)$; second parity vs. third or later parities, $\mathrm{HR}=0.91(P=0.48)$; history of clinical mastitis, $\mathrm{HR}=2.23(P<0.01)$; milk yield, $\mathrm{HR}=1.04(P<0.01)$; and $\operatorname{lnCMSCC}, \mathrm{HR}=1.31$ $(P<0.01)$. Removing lnCMSCC from the models further reduced the difference in the hazard of treatment for culling for mastitis between sparse and rich growth of Staph. aureus resulting in HR of $1.67(P<0.01)$ and $1.65(P<0.01)$ respectively.

\section{Case 2: Relationships Between Microbiological Diagnoses and Culling for Mastitis}

The primary reasons for culling as reported by the farmers that own the sampled herds are presented in

Table 5. Relationships between treatment of clinical mastitis and covariates, predicted by a random effects Cox proportional hazard model for time-dependent data ${ }^{1}$

\begin{tabular}{|c|c|c|c|c|c|}
\hline Covariate & & $\beta$ & $\mathrm{SE}$ & $P$-value & $\begin{array}{l}\text { Hazard } \\
\text { rate }\end{array}$ \\
\hline No pathogens & & - & - & - & - \\
\hline Staphylococcus & $>1,500 \mathrm{cfu}$ & 0.171 & 0.159 & 0.28 & 1.19 \\
\hline aureus $^{2}$ & $\leq 1,500 \mathrm{cfu}$ & 0.368 & 0.142 & 0.01 & 1.45 \\
\hline First parity & & -0.056 & 0.142 & 0.69 & 0.95 \\
\hline Second parity & & -0.113 & 0.136 & 0.41 & 0.89 \\
\hline Third or higher parities & & - & - & - & - \\
\hline $\mathrm{LnCMSCC}^{3}$ & & 0.194 & 0.044 & $<0.01$ & 1.21 \\
\hline Previous history of mastitis ${ }^{4}$ & & 0.739 & 0.118 & $<0.01$ & 2.09 \\
\hline Milk yield & & 0.035 & 0.009 & $<0.01$ & 1.04 \\
\hline
\end{tabular}

${ }^{1}$ The animals entered the risk set at the time of sampling for microbiological analysis and were observed until treatment of clinical mastitis, until culling, or for $500 \mathrm{~d}$ after calving $(\mathrm{n}=2,684)$.

${ }^{2} \mathrm{Rich}=>1,500 \mathrm{cfu}$, and sparse $=\leq 1,500 \mathrm{cfu}$ of coagulase-positive Staphylococcus $\mathrm{spp} . / \mathrm{mL}$ of milk.

${ }^{3}$ Logarithmic-transformed cow composite SCC.

${ }^{4}$ Clinical mastitis history indicates whether a cow had been treated for clinical mastitis before it was sampled for microbiological analysis during the current or previous lactation. 
Table 1. In case 2, the relationship between culling for mastitis and the covariates were investigated. With microbiological diagnosis categorized as no pathogens, Staph. aureus, Strep. spp., and CNS or other pathogens, the following estimated HR were obtained: isolation of Staph. aureus vs. no pathogens, HR $=1.87(P<0.01)$; isolation of Strep. spp. vs. no pathogens, HR $=2.13$ $(P=0.02)$; isolation of CNS or other pathogens vs. no pathogens, HR = $1.19(P=0.57)$; first parity vs. third or later parities, $\mathrm{HR}=0.64(P=0.06)$; second parity vs. third or later parities, $\mathrm{HR}=0.80(P=0.27)$; history of clinical mastitis, $\mathrm{HR}=3.23(P<0.01)$; milk yield, $\mathrm{HR}=1.03(P=0.02)$; and $\operatorname{lnCMSCC}, \mathrm{HR}=1.63(P<$ 0.01 ). Omitting the latter variable from the analysis strengthened the association between milk culture results and hazard of culling for mastitis such that the following HR were obtained: isolation of Staph. aureus vs. no pathogens, HR $=2.57(P<0.01)$; isolation of Strep. spp. vs. no pathogens, HR $=3.39(P<0.01)$; isolation of CNS or other pathogens vs. no pathogens, HR $=1.46(P=0.22)$.

The relationship between culling for mastitis and the covariates produced the following HR, when microbiological diagnosis was categorized as no pathogens or rich or sparse growth of Staph. aureus: rich growth of Staph. aureus vs. no pathogens, HR $=2.1(P<0.01)$; sparse growth of Staph. aureus vs. no pathogens, HR = $1.56(P=0.07)$; first parity vs. third or later parities, HR $=0.94(P=0.80)$; second parity vs. third or later parities, $\mathrm{HR}=0.96(P=0.87)$; history of clinical mastitis, $\mathrm{HR}=3.3(P<0.01)$; milk yield, $\mathrm{HR}=1.04(P<0.01)$; and $\operatorname{lnCMSCC}, \mathrm{HR}=1.62(P<0.01)$. After $\operatorname{lnCMSCC}$ was omitted from the model, the estimated HR for rich $[3.18(P<0.01)]$ and sparse $[1.97(P<0.01)]$ growth of Staph. aureus continued to reflect an increased likelihood of culling among cows with milk cultures of $>1,500$ $\mathrm{cfu} / \mathrm{mL}$.

\section{Case 3: Relationships Between Microbiological Diagnoses and Culling For All Reasons}

The relationships between culling for all reasons and the covariates Staph. aureus, Strep. spp., CNS or other pathogens, no pathogens, parity, milk yield, lnCMSCC, and clinical mastitis history are reported in Table 6. Specifically, the hazard of culling among Staph. aureuspositive cows was $30 \%$ higher than the hazard for cows negative upon microbiological milk culture. The hazard of culling was not increased among cows positive for Strep. spp. or CNS or other pathogens. Furthermore, relative to cows with no history of clinical mastitis, cows that had been treated for clinical mastitis previously were $72 \%$ more likely to be culled than herdmates with no recordings of the disease. Omitting $\operatorname{lnCMSCC}$ from the models did not provide significant estimates for the hazard of culling for all reasons in the milk culture categories: for Streptococcus spp., HR $=1.22(P=0.28)$, and for CNS or other pathogens, HR=1.13 $(P=0.38)$, whereas the HR for Staph. aureus was $1.47(P<0.01)$.

The relationships between general culling and rich or sparse growth of Staph. aureus, no pathogens, parity, milk yield, lnCMSCC, and clinical mastitis history are reported in Table 7. This analysis shows a significantly increased risk for culling among cows with rich growth of Staph. aureus upon microbiological milk culture as compared with cows in which no pathogens were found. The corresponding comparison for sparse growth of Staph. aureus was not associated with an increased hazard of culling. However, omitting lnCMSCC from the analysis revealed significant associations with culling for all reasons both for rich growth of Staph. aureus $[\mathrm{HR}=1.52(P<0.01)]$, and for sparse growth of Staph. aureus $[\mathrm{HR}=1.27(P=0.04)]$, as compared with cows with a negative milk culture for mastitis pathogens

\section{DISCUSSION}

In the present study, lnCMSCC was found to be related to the likelihood of both treatment of clinical mastitis and culling in all models. The LnCMSCC around the time of bacteriological sampling was included as a covariate in the models to adjust for the degree of inflammation. Furthermore, it is expected that much of the effect of previous subclinical and chronic mastitis on the likelihood of treatment of clinical mastitis, and likelihood of culling have been accounted for by adjusting for history of clinical mastitis in the analyses. Hence, the main models describe culture results that are unbiased concerning differences in previous udder health and CMSCC. However, the association between positive milk cultures for mastitis pathogens and SCC is well documented (Harmon, 1994; De Haas et al., 2002) and adjustment for lnCMSCC in the model may conceal associations between culture results and the outcome variables that would otherwise become apparent. Therefore, results from models without inclusion of the lnCMSCC have also been reported in the present investigation.

This study differs from previous reports in that a relatively higher proportion of Staph. aureus was found upon microbiological analysis (Wilson et al., 1997; Sargeant et al., 2001). This corresponds with the fact that Staph. aureus is the most predominant mastitis pathogen in Norway and is estimated to be responsible for $47 \%$ of clinical cases of mastitis. For comparison, Strep. dysgalactie, CNS, and coliform bacteria were isolated in approximately 16,8 , and $7 \%$ of clinical cases, respectively (NDHRS, 2004). 
Table 6. Relationships between culling for all reasons and covariates, predicted by a random effects Cox proportional hazard model for time-dependent data ${ }^{1}$

\begin{tabular}{|c|c|c|c|c|}
\hline Covariate & $\beta$ & $\mathrm{SE}$ & $P$-value & $\begin{array}{l}\text { Hazard } \\
\text { rate }\end{array}$ \\
\hline No pathogens & - & - & - & - \\
\hline Staphylococcus aureus ${ }^{2}$ & 0.264 & 0.092 & $<0.01$ & 1.30 \\
\hline Streptococcus spp. & 0.029 & 0.190 & 0.88 & 1.03 \\
\hline CNS or other pathogens ${ }^{3}$ & 0.016 & 0.137 & 0.91 & 1.02 \\
\hline First parity & -0.537 & 0.104 & $<0.01$ & 0.58 \\
\hline Second parity & -0.281 & 0.099 & $<0.01$ & 0.76 \\
\hline Third or higher parities & - & - & - & - \\
\hline $\operatorname{LnCMSCC}^{4}$ & 0.200 & 0.033 & $<0.01$ & 1.22 \\
\hline Previous history of mastitis ${ }^{5}$ & 0.543 & 0.090 & $<0.01$ & 1.72 \\
\hline Milk yield & 0.011 & 0.007 & 0.08 & 1.01 \\
\hline
\end{tabular}

\footnotetext{
${ }^{1}$ The animals entered the risk set at the time of sampling for microbiological analysis and were observed for culling within $500 \mathrm{~d}$ after calving or censoring $(\mathrm{n}=3,075)$.

${ }^{2}$ Coagulase-positive Staphylococcus spp.

${ }^{3}$ Coliform bacteria, including Escherichia coli; Enterococcus spp.; Arcanobacter pyogenes; Bacillus spp.; and yeast.

${ }^{4}$ Logarithmic transformed cow composite somatic cell count.

${ }^{5}$ Clinical mastitis history indicates whether a cow had been treated for clinical mastitis before it was sampled for microbiological analysis during the current or previous lactation.
}

The prevalence of positive milk cultures for Staph. aureus was higher in the present investigation as compared with a recent and comparable Finnish investigation (Pitkälä et al., 2004; Østerås et al., 2006). The difference in prevalence between the present study and the Finnish study was due to the fact that isolates with sparse growth of Staph. aureus were not reported in the latter (Pitkälä et al., 2004), whereas all isolates of Staph. aureus were included in our sampled material. This motivated us to investigate whether there are differences in the relationship of treatment of clinical mastitis and culling between isolates of rich and sparse growth of Staph. aureus that justify the practice of omitting the latter when the prevalence of Staph. aureus is reported. The 1,500-cfu/mL threshold value between rich and sparse growth of Staph. aureus was chosen because it is used in the official Norwegian procedure of the National Veterinary Institute (Aursjø et al., 1993).

\section{Relationships Between Microbiological Diagnoses and Treatment of Clinical Mastitis, and the Joint Event of Either Treatment or Culling for Mastitis}

The covariates of monthly milk yield, bimonthly lnCMSCC, previous clinical mastitis history, and parity were all obtained at cow level and microbiological analyses were conducted at quarter level. Because the NDHRS does not have records on treatment of clinical

Table 7. Relationships between culling for all reasons and covariates, predicted by a random effects Cox proportional hazard model for time-dependent data ${ }^{1}$

\begin{tabular}{|c|c|c|c|c|c|}
\hline Covariate & & $\beta$ & $\mathrm{SE}$ & $P$-value & $\begin{array}{l}\text { Hazard } \\
\text { rate }\end{array}$ \\
\hline No pathogens & & - & - & - & - \\
\hline \multirow{2}{*}{ Staphylococcus aureus ${ }^{2}$} & $>1,500 \mathrm{cfu}$ & 0.285 & 0.121 & 0.02 & 1.33 \\
\hline & $\leq 1,500 \mathrm{cfu}$ & 0.154 & 0.114 & 0.18 & 1.17 \\
\hline First parity & & -0.447 & 0.111 & $<0.01$ & 0.64 \\
\hline Second parity & & -0.233 & 0.106 & 0.03 & 0.79 \\
\hline Third or higher parities & & - & - & - & - \\
\hline $\mathrm{LnCMSCC}^{3}$ & & 0.171 & 0.035 & $<0.01$ & 1.19 \\
\hline Previous history of mastitis ${ }^{4}$ & & 0.486 & 0.095 & $<0.01$ & 1.63 \\
\hline Milk yield & & 0.009 & 0.007 & 0.18 & 1.01 \\
\hline
\end{tabular}

${ }^{1}$ The animals entered the risk set at the time of sampling for microbiological analysis and were observed for culling within $500 \mathrm{~d}$ after calving or censoring $(\mathrm{n}=2,684)$.

${ }^{2} \mathrm{Rich}=>1,500 \mathrm{cfu}$, and sparse $=\leq 1,500 \mathrm{cfu}$ of coagulase-positive Staphylococcus spp./mL of milk.

${ }^{3}$ Logarithmic-transformed cow composite SCC.

${ }^{4}$ Clinical mastitis history indicates whether a cow had been treated for clinical mastitis before it was sampled for microbiological analysis during the current or previous lactation. 
mastitis at quarter level, comparisons between microbiological diagnoses and treatment of clinical mastitis were conducted at cow level. This limitation should be taken into account when the findings of the study are interpreted. However, it could be argued that a significantly higher risk of infection from infected to uninfected quarters within cow may give reason for approaching the problem at cow level (Zadoks et al., 2001). Because reasons for culling were recorded by the farmer, and therefore possibly less accurate than veterinary diagnoses, the latter were preferred when likelihood of mastitis was assessed in the present investigation. However, to avoid the issue of informative censoring, analyses were also performed with mastitis defined jointly as either treatment or culling for the disease.

Staphylococcus aureus is the most frequently isolated mastitis pathogen in Norway (NDHRS, 2004), and its ability to cause subclinical IMI (Harmon, 1994) is well documented. An untreated subclinical infection might show clinical flare-ups at a later time (Swinkels et al., 2005). This could explain our finding that the likelihood of treatment of clinical mastitis was significantly higher among cows in which Staph. aureus was isolated compared with cows with a negative milk culture. Corresponding comparisons for cows in which pathogens other than Staph. aureus were isolated proved to be significant for Strep. spp. when lnCMSCC was removed from the model and the outcome was defined jointly as either treatment of clinical mastitis or culling for mastitis. These findings point toward the conclusion that even subclinical infection or a colonization of the teat canal and cistern with Staph. aureus may be followed by culling or treatment with appropriate antibiotic drugs. A similar tendency, although less pronounced, was observed also among Strep. spp., whereas the isolation of other pathogenic bacteria was less likely to be followed by treatment or culling.

Stage of lactation has been identified as an important risk factor for mastitis in dairy cows (Barkema et al., 1998; Zadoks et al., 2001); the analyses presented here adjust for factors such as milk yield, lnCMSCC, and history of clinical mastitis that vary throughout stage of lactation, in that each observation entered the risk set at the time of sampling for microbiological diagnosis. Previous studies have also shown that the diagnosis of mastitis pathogens is related to high milk yield and elevated SCC (De Haas et al., 2002, Gröhn et al., 2004). To improve the assessment of a cause-and-effect relationship between treatment of clinical mastitis and the covariates, we used values for milk yield and lnCMSCC obtained around the time of microbiological diagnosis. A potential problem in the present analyses is that values used for milk yield and lnCMSCC in the present analyses were not obtained at the event time, but rather the most recent available value was used. This "last value carried forward" approach provides potential for biased estimates (Prentice, 1982). However, modeling these longitudinal processes in a joint longitudinal and survival framework will alleviate such biases. We are currently developing statistical models that address these issues. In particular, we are investigating varying coefficient models (Hastie and Tibshirani, 1993) and models for the joint analysis of longitudinal and time to event data (Tsiatis and Davidian, 2004).

We have not been able to adjust for episodes of subclinical or clinical IMI before microbiological sampling when previous treatments have not been recorded. In those cases, measures of milk yield and lnCMSCC might be more closely related to previous clinical mastitis history rather than predisposing for a positive milk culture. However, as a whole, the present investigation demonstrated that elevated milk yield and lnCMSCC at the time of microbiological sampling are associated with treatment of clinical mastitis at a later point in time. Zadoks et al. (2001) also found the previous quarter SCC to be related to mastitis in the same quarter. Previous treatment of clinical mastitis during the current or preceding lactation was highly predictive of recurrence of the disease in the present study. Similarly, it has been reported that previous IMI with Staph. aureus or Strep. uberis is predictive of recurrence of IMI caused by either bacteria at quarter level (Zadoks et al., 2001). In the same study, a significantly higher incidence rate of Strep. uberis mastitis was found among cows in the third or higher parity (Zadoks et al., 2001). This is in line with a numeric decrease in the hazard rate for mastitis as seen in the present study among cows in the first and second parity.

The likelihood of treatment of clinical mastitis was not increased for cows diagnosed with rich growth of Staph. aureus compared with cows in which no pathogens were isolated. A significant association was first found when the outcome variable was broadened to include cows culled for mastitis together with cows treated for clinical mastitis, and when lnCMSCC was omitted from the analyses. As confirmed in the analyses of culling for all reasons and culling for mastitis, cows with rich growth of Staph. aureus tended to be culled, and cows with sparse growth of the bacteria tended to be treated. The latter is particularly interesting in view of the fact that microbiological findings were not reported to the farmers. Thus, a significant number of cows with 1,500 colonies or less of Staph. aureus $/ \mathrm{mL}$ of milk developed clinical mastitis after bacteriological sampling. Variation in the number of colony-forming units not only reflects the degree of IMI, but also indicates fluctuation in the shedding of the bacteria over time as described by Sears et al. (1990). The same study 
concluded that $40 \%$ of cows shedding an average of less than 1,000 cfu of Staph. aureus/mL would be missed by a single analysis based on inoculation of $0.01 \mathrm{~mL}$ of quarter milk. Deluyker et al. (2005) and Dingwell et al. (2003) have associated high shedding levels of Staph. aureus with poor prognosis after treatment during lactation and the dry period, respectively. This may explain why high-shedding cows are more likely to be culled than low-shedding cows.

\section{Relationships Between Microbiological Diagnoses and Culling}

Culling rates have been shown to be associated with parity (Gröhn et al., 1998), SCC (Caraviello et al., 2005; De Vliegher et al., 2005) and clinical mastitis (Gröhn et al., 1998; Neerhof et al., 2000). In agreement with previous reports (Gröhn et al., 1998), our study showed that overall culling rates were significantly lower for both first- and second-parity cows when compared with cows in the third or later parities. The parity differences were less pronounced when culling for mastitis was assessed separately. Increased $\operatorname{lnCMSCC}$ at the time of bacteriological sampling was related to a higher culling rate in the present investigation, which is reflected in other recent publications that have concentrated on SCC during the first 2 mo of lactation and culling of dairy heifers (De Vliegher et al., 2005). The proportion of cows culled because of udder health problems is in accordance with previous reports (De Vliegher et al., 2005). No relationship was found between milk yield at the time of bacteriological analysis and culling for all reasons after adjustment for microbiological diagnoses, parity, clinical mastitis history, and lnCMSCC at the time of bacteriological analysis, which is in contrast to earlier studies (Beaudeau et al., 1995; Gröhn et al., 1998; De Vliegher et al., 2005). The likelihood of culling for mastitis was significantly increased with higher milk production at the time of bacteriological sampling, which may indicate that cows high in milk were more susceptible for mastitis. High milk producers were also found to be more likely to be treated for clinical mastitis in the present study.

Staphylococcus aureus was associated with the likelihood of culling for all reasons and culling because of mastitis, whereas pathogens other than Staph. aureus were not associated with culling for all reasons. An association was found between Strep. spp. and culling because of mastitis, whereas other mastitis pathogens were not associated with culling for mastitis also after lnCMSCC was omitted from the analysis. These findings emphasize the importance of Staph. aureus as the primary causative agent for mastitis in Norway.

\section{CONCLUSIONS}

Viewed as a whole, the present study indicates that a positive diagnosis of Staph. aureus under microbiological quarter milk analysis correlates with later treatment of clinical mastitis and culling after adjustment is made for clinical mastitis history and lnCMSCC in a random sample of the Norwegian cow population. These relations were not apparent for Strep. spp., although the joint event of either treatment or culling for mastitis proved significant when lnCMSCC was omitted from the statistical analysis. A positive milk culture for Strep. spp was, however, related to culling for mastitis also in the model that corrected for lnCMSCC. It is also worth noting that cows with sparse growth of Staph. aureus upon microbiological analysis were likely to be treated for clinical mastitis and cows with rich growth of the bacteria experienced a high risk of culling. The latter findings emphasize the importance of including isolates both with rich and sparse growth of Staph. aureus in studies related to this mastitis pathogen.

\section{ACKNOWLEDGMENTS}

The study was supported by a grant from the Research Council of Norway. Great thanks to all advisors in TINE Norwegian Dairies for taking all the milk samples. Access to production and health data was given by the Norwegian Dairy Herd Recording System and the Norwegian Cattle Health Services in agreement number 1 in 2002. We would like to thank Ralph Nash at Nash Project Services for his assistance in editing this manuscript.

\section{REFERENCES}

Allison, P. D. 1995. Survival Analysis Using the SAS system. 1st ed. SAS Institute, Cary, NC.

Aursjø, J., D. Lindheim, O. Reksen, M. Skjervheim, T. Slettbakk, L. Sølverød, and S. Waage. 1993. Laboratorierutiner for mastittdiagnostikk ved Statens veterinære laboratorier. Statens Veterinære Laboratorier, Oslo, Norway.

Barkema, H. W., Y. H. Schukken, T. J. G. M. Lam, M. L. Beiboer, H. Wilmink, G. Benedictus, and A. Brand. 1998. Incidence of clinical mastitis in dairy herds grouped in three categories by bulk milk somatic cell counts. J. Dairy Sci. 81:411-419.

Beaudeau, F., V. Ducrocq, C. Fourichon, and H. Seegers. 1995. Effect of disease on length of productive life of French Holstein dairy cows assessed by survival analysis. J. Dairy Sci. 78:103-117.

Caraviello, D. Z., K. A. Weigel, G. E. Shook, and P. L. Ruegg. 2005. Assessment of the impact of somatic cell count on functional longevity in Holstein and Jersey cattle using survival analysis methodology. J. Dairy Sci. 88:804-811.

De Haas, Y., H. W. Barkema, and R. F. Veerkamp. 2002. The effect of pathogen-specific clinical mastitis on the lactation curve for somatic cell count. J. Dairy Sci. 85:1314-1323.

Deluyker, H. A., S. N. Van Oye, and J. F. Boucher. 2005. Factors affecting cure and somatic cell count after pirlimycin treatment of subclinical mastitis in lactating cows. J. Dairy Sci. 88:604-614.

De Vliegher, S., H. W. Barkema, G. Opsomer, A. De Kruif, and L. Duchateau. 2005. Association between somatic cell count in early 
lactation and culling of dairy heifers using Cox frailty models. J. Dairy Sci. 88:560-568.

Dingwell, R. T., K. E. Leslie, T. F. Duffield, Y. H. Schukken, L. Des Coteaux, G. P. Keefe, D. F. Kelton, K. D. Lissemore, W. Shewfelt, P. Dick, and R. Bagg. 2003. Efficacy of intramammary tilmicosin and risk factors for cure of Staphylococcus aureus infection in the dry period. J. Dairy Sci. 86:159-168.

Gröhn, Y. T., S. W. Eicker, V. Ducrocq, and J. A. Hertl. 1998. Effect of disease on the culling of Holstein dairy cows in New York State. J. Dairy Sci. 81:966-978.

Gröhn, Y. T., D. J. Wilson, R. N. Gonzalez, J. A. Hertl, H. Schulte, G. Bennet, and Y. H. Schukken. 2004. Effect of pathogen-specific clinical mastitis on milk yield in dairy cows. J. Dairy Sci. 87:3358-3374

Harmon, R. J. 1994. Physiology of mastitis and factors affecting somatic cell counts. J. Dairy Sci. 77:2103-2112.

Hastie, T. J., and R. J. Tibshirani. 1993. Varying Coefficient Models. J. R. Stat. Soc. [Ser A] 55:757-776.

International Dairy Federation. 1981. Laboratory methods for use in mastitis work. IDF Bull. No. 132. Int. Dairy Fed., Brussels, Belgium.

International Dairy Federation. 1987. Bovine mastitis. Definition and guidelines for diagnosis. IDF Bull. No. 211. Int. Dairy Fed., Brussels, Belgium.

Neerhof, H. J., P. Madsen, V. Ducrocq, A. R. Vollema, J. Jensen, and I. R. Korsgaard. 2000. Relationships between mastitis and functional longevity in Danish Black and White dairy cattle estimated using survival analysis. J. Dairy Sci. 83:1064-1071.

Norwegian Dairy Herd Recording System (NDHRS). 2004. Annual statistics (Årsrapport, Helsetjenesten for storfe). Norwegian Dairy Herd Recording System, Ås, Norway.
Østerås, O. 2002. Helsekortordninga 2001 (The health card annual report). Nor. Vet. Tidsskr. 114:481-492.

Østerås, O., L. Sølverød, and O. Reksen. 2006. Subclinical mastitis bacteria isolated in milk from randomly selected Norwegian dairy cows. J. Dairy Sci. 89:1010-1023.

Pitkälä, A., M. Haveri, S. Pyörälä, V. Myllys, and T. HonkanenBuzalski. 2004. Bovine mastitis in Finland 2001-Prevalence, distribution of bacteria, and microbiological resistance. J. Dairy Sci. 87:2433-2441.

Prentice, R. 1982. Covariate measurement errors and parameter estimates in a failure time regression model. Biometrika 69:331-342.

Sargeant, J. M., K. E. Leslie, J. E. Shirley, B. J. Pulkrabek, and G. H. Lim. 2001. Sensitivity and specificity of somatic cell count and California Mastitis Test for identifying intramammary infection in early lactation. J. Dairy Sci. 84:2018-2024.

Sears, P. M., B. S. Smith, P. B. English, P. S. Herer, and R. N. Gonzalez. 1990. Shedding pattern of Staphylococcus aureus from bovine intramammary infections. J. Dairy Sci. 73:2785-2789.

Swinkels, J. M., H. Hogeveen, and R. N. Zadoks. 2005. A partial budget model to estimate economic benefits of lactational treatment of subclinical Staphylococcus aureus mastitis. J. Dairy Sci. 88:4273-4287.

Tsiatis, A. A., and M. Davidian. 2004. An overview of joint modeling of longitudinal and time-to-event data. Statist. Sin. 793-818.

Wilson, D. J., R. N. Gonzalez, and H. H. Das. 1997. Bovine mastitis pathogens in New York and Pennsylvania: Prevalence and effects on somatic cell count and milk production. J. Dairy Sci. 80:2592-2598.

Zadoks, R. N., H. G. Allore, H. W. Barkema, O. C. Sampimon, G. J. Wellenberg, Y. T. Gröhn, and Y. H. Schukken. 2001. Cow- and quarter-level risk factors for Streptococcus uberis and Staphylococcus aureus infection. J. Dairy Sci. 84:2649-2663. 